Vol-2, Issue-4, 2018 (IJEBAR)

ISSN: 2614-1280

http://www.jurnal.stie-aas/ijebar

\title{
THE EFFECT OF THE PERCEPTION OF SERVICE QUALITY ON THE DECISION OF PURCHASE IN DAWET JABUNG TRADERS IN PONOROGO
}

\author{
Titin Eka Ardiana \\ Accounting Study Program, Faculty of Economics \\ Universitas Muhammadiyah Ponorogo \\ Email: titineka31@gmail.com
}

\begin{abstract}
This study aims to find out: to find out whether there is an influence on the perception of Service Quality on Repurchase Decisions on Dawet Jabung Traders in Ponorogo. This study uses a quantitative approach with a sample of all customers who have made purchases at the Dawet Jabung UKM in Mlarak District, Ponorogo Regency. The variable of this study consists of one independent variable, namely the perception of service quality (X1) and one dependent variable, namely the purchasing decision (Y). Data collection is done using indirect questionnaires or techniques. The results of data collection were then analyzed using simple and multiple linear regression analysis techniques with the help of SPSS Version 20. The results showed that: (1) Variable perceptions of service quality in this study were able to explain $9.4 \%$ variation in the Dawet Jabung Ponorogo MSME decision. While the remaining $90.6 \%$ is explained by variables or aspects outside the model, and (2) From the results of the F test shows that the perception variable service quality is a feasible variable to test the variable repurchase decisions in dawet UMKM Jabung Ponorogo .
\end{abstract}

Keywords : Perception Of Service Quality, Purchasing Decisions

\section{Introduction}

In the current era of holistic marketing, the development of the company is inseparable from the development of its consumers. According to Kotler and Keller (2011: 18) the concept of holistic marketing is based on design, development, implementation of marketing programs, processes, and activities that are broad and interrelated. This concept is very concerned about the needs and desires of consumers in the company's marketing program. Companies that are able to meet the needs and desires of consumers can encourage consumers to use the company's products.

The quality perception in this study is about the context of perceptions of service quality. Repurchase intention is influenced by perceptions of service quality. In the study also explained that there is a positive relationship between the perception of service quality and intention to repurchase (Meng, 2011). In the study, the perception of quality has a positive effect on repurchase intention (Puspitasari, 2006). Like the perception of service quality, brand image can affect repurchase intention. In research that shows the significance level of brand awareness or brand association as a sub dimension of brand equity has a positive relationship with perceived value and intention to revisit (Yaqian, 2011).

Theoretically, every time someone buys an item or service, he hopes that the goods or services will be able to provide 
maximum usability. This is in line with the opinion of Tjiptono (2008: 179) that every consumer is a rational economic man who has rational reasons and makes rational choices in every purchase of products and services. Consumers become more observant in choosing a company that is permanent and appropriate to get the product or service they want.

In this case the perception of service quality is one of the factors that influence consumer interest to make a repeat purchase of a company. Repurchasing is a real reaction to the success of a product's marketing program. Companies must be able to create a good marketing strategy to be able to create that success. One of them is creating good quality service for the products offered.

According to Aaker (2008: 124) perceived quality can be defined as customer perceptions of the overall quality or superiority of a product or service related to what is expected by the customer. Perception of quality cannot be determined objectively because it is a perception and involves what is important to the customer. High quality perceptions of a brand will form a positive image for the brand which is one factor to make a purchase. Like dawet traders, they always offer quality products.

This can be seen from the products offered such as food and beverages. Dawet traders also always prioritize service and satisfaction and convenience of consumers in shopping. Dawet traders always train their employees to always be friendly and responsive to their customers by providing a suggestion box if there are complaints and information sections that are formed to help customers get the information they need.
Another factor that also affects repurchase is customer satisfaction. Customer satisfaction is a level of feeling where someone states the results of a comparison of the performance of the product or service received and expected. Many ways that companies use to satisfy consumer needs. Companies that have been able to satisfy consumers and have loyal consumers tend to be able to survive changes in economic conditions. Consumers will provide a specific response as a result of evaluating the gap between expectations and product performance.

This satisfaction will be achieved if the consumer's expectations regarding the value of a product are in accordance with the value received. If consumers feel satisfied, then most likely the consumer will make a repeat purchase. But in the opposite condition, if the consumer feels dissatisfied then it is likely to move to buy another product and not use the product again.

Perception of service quality is the customer's perception of the overall purchasing service. Customer perceptions of the service quality of dawet traders will be able to have a positive impact on customers who will then create interest for customers to make a decision to make purchases at the dawet jabung traders.

In Indonesia, SMEs are a business that is much cultivated by the community because in terms of capital it is relatively more affordable. The Cooperative has a very large and significant role for the survival of Indonesian people, the majority of which are the lower middle class. But in reality the development of SMEs has experienced many problems, both internal 
(problems originating from within the UKM) and external issues (problems originating from outside the UKM) so that the development of SMEs in Indonesia is still lagging behind other countries.

In general, the SME problem that occurs in Indonesia is the low performance of SMEs themselves. This can be seen from the low profitability of SMEs, making it difficult to develop and compete with other SMEs. The low performance of SMEs is related to service quality, lack of innovation, and the Human Resources (HR) owned by SMEs to satisfy customers.

With the large number of business people (SMEs) it will lead to very tight and competitive competition so that it will spur business people to always create customer satisfaction so that their business can gain greater profits. Not only that, in the competition it encouraged business people to create something different that was not owned by similar businesses. Customers are an important factor in the development of a business. Customer satisfaction in a business or business will have a huge impact on the development of the business. This is in line with (Kotler, 2001: 21), namely satisfaction is defined as the pleasure or disappointment of someone comparing the product performance that is felt in the relationship and expectations.

Based on previous observations, the phenomenon of gaps obtained by Dawet Jabung entrepreneurs in Ponorogo District, Mlarak District is that there are still many customers who are not satisfied with the services provided so that customers have not given good loyalty and this can cause losses to business people or traders in the future.
There are quite a number of SME business people in the Dawet Jabung area who have not been able to give a maximum role to the customers so that the results obtained are not in line with the expectations of traders. This is due to the lack of quality service provided to customers resulting in little profit for traders. Customer satisfaction is one of the important variable components to always be maintained and maintained because with feeling happy or in accordance with the expectations of customers, customers will be able to make repeat purchases and even recommend to friends or closest friends to try to make purchases at that place.

In addition to the above, managerial skills or the ability to manage good business are needed so that businesses can run well in conducting SME operational activities, because the better the managerial ability of SMEs in managing their business, the better the output will be, as well as the quality service of SMEs, if an SME conducts responsiveness, or responsiveness, that is a willingness to help and provide fast and appropriate service to customers, with clear information delivery, it will be able to meet expectations and feelings of pleasure for customers, especially for repurchasing for SME businesses in Dawet Jabung, Mlarak District, Ponorogo Regency. Based on the description of the problems mentioned above, the researcher will conduct a study with the title: "The Effect of Service Quality Perceptions on Repurchase Decisions on Dawet Jabung Traders in Ponorogo." 


\section{Literature Review and Development of Hypothesis}

\subsection{Perception of Service Quality}

Quality of service is a necessity that must be done in an effort to be able to survive and still gain customer trust. The consumption patterns and lifestyle of customers require a business to be able to provide quality services. The success of a business in providing quality services can be determined by the service quality approach that has been developed by Parasuraman, Berry and Zenthaml (in Lupiyoadi, 2006: 181). There are five dimensions of service quality according to Parasuraman in Lupiyoadi (2006: 182), namely:

a. Tangibles, or physical evidence, namely the ability of a business to show its existence to external parties. What is meant is that the appearance and ability of the facilities and physical infrastructure of a business and the state of the surrounding environment are clear evidence and services provided.

b. Reliability, or reliability, is the ability of a business to provide services that are promised accurately and reliably.

c. Responsiveness, or responsiveness, is a willingness to help and provide fast and appropriate service to customers, with the delivery of clear information.

d. Assurance, or assurance and certainty, namely knowledge, politeness, and the ability of employees to attempt to foster trust in customers to a business. Consists of several components including communication, credibility, security, competence and courtesy.

e. Empathy, which is giving genuine and individual or personal attention given to customers by trying to understand the customer's desires. For example, a business must know the customer's desires specifically from the physical form of the product or service to the right distribution.

\subsection{Repurchase Decisions}

Kotler and Keller (2009) explain that the decision making process is a basic psychological process that plays an important role in understanding how consumers actually make purchasing decisions. Kotler and Keller (2009) explain that the decision making process is a basic psychological process that plays an important role in understanding how consumers actually make purchasing decisions (Hawkins, 2009):
a. Product
b. Choice of brands
c. Amount of purchase
d. Time of Purchase
e. Payment method

\subsection{Hypothesis}

The development of hypotheses developed in this study are as follows:

H1: Perception of Service Quality has a Positive Effect on Repurchase Decisions

\section{RESEARCH METHODS}

\subsection{Research Population}

The population in this study were all customers who had made purchases at the Dawet Jabung UKM in Ponorogo Regency.

\subsection{Research Samples}

The sample in this study were all customers who had made purchases at the Dawet Jabung UKM in Mlarak District, Ponorogo Regency. The number of samples in this study were 96 people.

The data collection tool in this study uses indirect techniques. Questionnaire is a 
data collection tool in the form form and distributed to capture information about something consisting of questions to be answered by respondents in detail.

\subsection{Operational Definitions and Variable} Measurements

\subsubsection{Perception of Service Quality}

According to Sekaran and Bougie (2013), there are variables that affect the dependent variable, both positively and negatively. In this study the independent variable is the perception of service quality consisting of Tangible, Reliability, Responsiveness, Assurance, and Empathy.

\subsubsection{Repurchase Decisions}

According to Siregar (2013), there are variables that are affected or which are due to other variables (independent variables). The dependent variable in this study is a repeat purchase decision.

\subsection{Analysis Techniques}

In this study to process data from the results of this study using inferential (quantitative) analysis. Where in the analysis using the SPSS version 20 program package. Simple linear regression is used to obtain mathematical relationships in the form of an equation between a single non-independent variable and a single independent variable. Simple linear regression only has one variable associated with one non-independent variable (Alan, 2012). Data analysis in this study was carried out with the help of Simple Linear Regression Methods and Multiple Linear Regression.

Regression analysis is useful to determine the magnitude of the influence between the Perception of Service Quality variables on the variable Repurchase Decision. From the questionnaire data that has been tabulated and carried out an analysis with the help of the SPSS version 20 program which is formulated as follows:

$$
\mathbf{Y}=\mathbf{a}+\mathbf{b} \mathbf{1} \mathbf{X}
$$

Information :

$\mathrm{Y}=$ Repurchase Decision, $\mathrm{a}=$ constant,

$\mathrm{b} 1=$ Regression coefficient, $\mathrm{X}=$ Service Quality Perception

\subsection{Hypothesis testing}

In this study to test hypotheses using the $t$ test. The $t$ test is a partial test which is used to test the relationship between independent variables individually and the dependent variable (Santoso, 2001).

\subsection{Classic assumption test}

To get a regression model that is not biased, it is necessary to test the classic assumptions including; multicollinearity test, autocorrelation and heterocedasticity (Ghozali, 2011).

\section{Results And Discussion}

\subsection{Analysis of Multiple Linear Regression}

Data analysis in this study will be conducted with multiple linear regression models, where in the regression analysis will examine the effect of perceived quality of service on repurchase decisions. Data processing uses the help of the SPSS v.20 program based on data obtained from 122 samples of research conducted.

Based on the results of multiple regression analysis carried out with the help of the SPSS v.20 program, where PKP (X) is used multiple regression analysis which can 
International Journal of Economics, Business and Accounting Research (IJEBAR)

Peer Reviewed - International Journal

Vol-2, Issue-4, 2018 (IJEBAR)

ISSN: 2614-1280

http://www.jurnal.stie-aas/ijebar

be seen in table 12. So the results of multiple regression analysis are obtained coefficients for PKP independent variables $=0.267$ with a cost of 5.773, so Regression equation models obtained are:

$$
\mathrm{MZ}=5,773+0,267 \mathrm{REL}+\mathrm{e}
$$

The regression model means:

a. Boarding value (PU) is 5.773, which means that if the Service Quality Perception is equal to zero, then the possibility of consumers to make a decision to re-buy Dawet Jabung is 5.773 .

b. PKP regression coefficient (Perception of Service Quality) from multiple linear calculations obtained coefficient value (b1) $=0.267$. This means that every time there is an increase in perceptions of service quality (PKP) of $1 \%$, then the likelihood of consumers taking a Repurchase Decision (PU) will increase by $0.267 \%$

\subsection{Simultaneous Testing (Test F)}

Simultaneous tests are used to determine whether the independent variables simultaneously or simultaneously affect the dependent variable.

Table 1

Simultaneous Significance Test (F Test)

\begin{tabular}{|l|l|c|c|c|}
\hline \multicolumn{2}{|c|}{ Model } & F & Sig. & Information \\
\hline \multirow{2}{*}{1} & $\begin{array}{l}\text { Regression } \\
\text { Residual } \\
\text { Total }\end{array}$ & 10,851 &, $001^{\mathrm{b}}$ & Significant \\
\cline { 2 - 5 } & & & \\
\cline { 3 - 5 } & & & & \\
\hline
\end{tabular}

Source: Results of Data Processing with SPSS

\subsection{Partial Test (t Test)}

Partial significance test aims to determine whether there is an influence of independent variables with variables related either partially. The results of the analysis of the partial significance test ( $T$ test) between the PKP independent variables on PU obtained the following results:

Table 2

Partial Significance Test (T Test)

\begin{tabular}{|l|c|c|c|c|c|}
\hline \multirow{2}{*}{ Model } & \multicolumn{2}{|c|}{$\begin{array}{c}\text { Unstandardized } \\
\text { Coefficients }\end{array}$} & $\begin{array}{c}\text { Standardized } \\
\text { Coefficients }\end{array}$ & \multirow{2}{*}{ T } & \multirow{2}{*}{ Sig. } \\
\cline { 2 - 4 } & B & Std. Error & Beta & & \\
\hline (Constant) & 5,773 & 1,900 & & 3,038 & 0,003 \\
\hline PKP & 0,267 & 0,081 & 0,322 & 3,294 & 0,001 \\
\hline
\end{tabular}

Source: Results of Data Processing with SPSS

From table 2 above can be known:

a. Hypothesis testing
Significant test of the correlation coefficient for $\mathrm{T}$ count test PKP variable $(\mathrm{X})$ is 3.294 
with a significant value of 0.001 . Significant value is smaller than $0.05(0.002>0.05)$ so that it can be said that the $\mathrm{T}$ value obtained is significant. So the hypothesis is accepted.

\section{Conclusions And Suggestions}

\subsection{Conclusion}

This study aims to examine whether the perceptions of service quality affect the decision to repurchase at UMKM Dawet Jabung in Ponorogo district. Researchers are interested in researching because they want to know empirically about the factors that influence the decision to repurchase at the Dawet Jabung Community Service in Ponorogo Regency. Based on previous research, it was explained that there was a positive relationship between perceptions of service quality and intention to repurchase (Meng, 2011). In studies showing perceived quality has a positive effect on repurchase intention (Puspitasari, 2006).

Based on the discussion of the hypothesis in the previous chapter, it is known that the hypothesis proposed is the perception of the quality of supported services. The decision to repurchase a product is influenced by many things. This study shows that perceptions of service quality have an influence on repurchase decisions in Dawet Jabung Ponorogo MSMEs.

\subsection{Suggestion}

Based on the results of the conclusions above, there are several recommendations recommended for future research. These suggestions are as follows.

a. Subsequent research must add independent variables that are able to explain the effect on the dependent variable which in this study is only able to explain $9.4 \%$.

b. Further research is recommended to design a deeper research model, especially in connecting variables that are interpersonal and external to consumers in deciding repurchases.

\section{REFERENCE}

Aaker, A. David. (2008). Brand Equity Management. Interpreting by Aris Ananda. Jakarta: Main Partner.

Alan. (2012). Simple Linear Regression Analysis. Http://www.scrib.com.23 October.

Ghozali, Imam. (2011). Application of Multivariate Analysis with the SPSS Program. Semarang: Diponegoro University Publishing Agency.

Ghozali, Imam. (2013). Application of Multivariate Analysis with IBM SPSS 21 Program PLS Regression update. Diponegoro University Publishing Agency

Hawkins, Del I., Mothersbaugh, David L. (2010). Consumer Behavior: Building Marketing Strategy. New York: McGraw-Hills.

Kotler, Philip and Kevin Lane Keller, "Marketing Management, Indonesian Language Edition", Issue 13, Erlangga, Jakarta, (2009)

Lupioyadi, Rambat and A. Hamdani. (2006). Service Marketing Management, Second Edition, Jakarta: Salemba Empat. 
Meng-Hsuan Li. (2011). The Influence of Perceived Quality Service on Brand Image, Word of Mouth, and Repurchase Intention: A Case Study of Min-Sheng General Hospital in Taoyuan, Taiwan. AU-GSB eJournal (Online) Vol. 4, (No. 1) pp. 91-105 (http://gsbejournal.au.edu accessed on November 1, 2012)

Parasuraman, Zeithmal, V.A, Berry, L.L., "The Behavioral Consequences of Service Journal of Economics Volume 4 Number 1, May 201364 Quality", Journal of Marketing, (No. 60). Thing 31 - 46, (1996)

Puspitasari, Diana. (2006). Analysis of the Effect of Quality Perception and Customer Satisfaction on the Repurchase Interest (Case Study of Garuda Airlines Departure Semarang). Thesis published. Semarang: Undip Postgraduate Program.

Now, Uma and Bougie, Roger. (2013). Research Methods for Business. United Kingdom: Wiley

Singgih, Santoso. (2001). "SPSS: Processing Statistics Data Professionally",
Jakarta: Publisher PT Elex Media Komputindo Gramedia Group, Member of IKAPI.

Tjiptono, Fandy. (2008). Marketing Services. Malang: Bayu Media Publishing Publisher.

Yaqian Zhou. (2011). The Impact of Customer-Based Brand Equity on Revisit Intentions: An Empirical Study of Business and Leisure Travelers at Five Shanghai Budget Hotels. AUGSB eJournal (Online) Vol. 4, (No. 1) pp. 168-181 (http://gsbejournal.au.edu accessed on November 1, 2012).

(2011). Application of Multivariate Analysis with SPSS 20. Program of the Diponegoro University Publishing Board. 